\title{
A new process of smelting laterite by low- temperature reduction and microwave irradiation
}

\author{
Lei Wang, Peimin Guo*, and Lingbing Kong \\ China Iron and Steel Research Institute, 76 Xueyuannan Road, Beijing 100081, China
}

\begin{abstract}
A new smelting process for the reduction of laterite with a relatively high yield of $\mathrm{Ni}$ has been presented in this paper; particularly, this process has been underwent industrialized experiment in China. This new process was based on the following fundamental research results. (1) Since nickel oxide can be reduced more easily than iron oxide, the nickel content of the produced ferronickel alloy increases significantly when the quantity of coal that is mixed with laterite ore is optimized, leading to a right oxygen potential of gas for reduction reaction. (2) When laterite is reduced at $1150^{\circ} \mathrm{C}$, only $75 \%$ of the reduced ferronickel product can be magnetically separated from slag, although more than $95 \% \mathrm{Ni}$ has been reduced from laterite. (3) The key technology is to realize a fast carburization at $1300^{\circ} \mathrm{C}$ by microwave irradiation, which causes ferronickel fines grow to a large size in the semi-melting state so that they can be separated magnetically with a high efficiency. The first demonstration production line with an annual capacity of $100 \mathrm{kt}$ green balls has been established in China. The $\mathrm{Ni}$ content reaches $13.5 \%$, moreover, both $\mathrm{P}$ and $\mathrm{S}$ contents are also within the expected range.
\end{abstract}

\section{Introduction}

Nickel resource is important in the world. About $80 \%$ of the total known nickel reserves are present as nickel oxide in the laterite ores [1]. Nevertheless, at the present time about $60 \%$ of the total metallic nickel production arises from the sulfide ore deposits [2]. There are a number of reasons for this disparity, the major one is economic and thus there is considerable incentive for the development of more efficient and profitable processes for the extraction of metallic nickel from these laterite ores. According to the $\mathrm{Ni}$ and Fe content, Laterite can be classified into three catalogues: limonite, intermediate and saprolite, shown in Table 1. The nickel content is over $1.8 \%$ and iron content is less than $25 \%$ for saprolite, which is suitable for RK-EF smelting; The nickel content is less than $1.5 \%$ and iron content is over $30 \%$ for limonite, which is suitable for BF process; The intermediate can be applied for $\mathrm{EF}$ or $\mathrm{BF}$ [3-5].

BF process needs over much coke and RK-EF needs over much electricity. With the surplus capacity of ferronickel and the unceasingly decreased price of metal nickel, Both

\footnotetext{
* Corresponding author: guopm@pku.org.cn
} 
BF and RK-EF processes lost their original economic advantages. So these existed processes need to be upgraded or new energy saving processes need to be developed.

Table 1. Distribution and composition of laterite.

\begin{tabular}{|c|c|c|c|c|c|}
\hline \multirow{2}{*}{ Ore bed } & \multicolumn{5}{|c|}{ Composition/wt, \% } \\
\cline { 2 - 6 } & $\mathrm{Ni}$ & $\mathrm{Co}$ & $\mathrm{Fe}$ & $\mathrm{Cr}_{2} \mathrm{O}_{3}$ & $\mathrm{MgO}$ \\
\hline Limonite & $0.8 \sim 1.5$ & $0.1 \sim 0.2$ & $40 \sim 50$ & $2 \sim 5$ & $0.5 \sim 5$ \\
\hline Intermediate & $1.5 \sim 1.8$ & $0.02 \sim 0.1$ & $25 \sim 40$ & $1 \sim 2$ & $5 \sim 15$ \\
\hline Saprolite & $1.8 \sim 3$ & $0.02 \sim 0.1$ & $10 \sim 25$ & $1 \sim 2$ & $15 \sim 35$ \\
\hline
\end{tabular}

We have developed a new process of low-temperature reduction combined with microwave smelting. Laterite ores underwent reduction and fresh ferronickel fines underwent gathering and growing up during the semi-molten state. A demonstrate production line showed that the new process is of the features such as low smelting temperature, low energy consumption and low emission. The main results are introduced here.

\section{Fundamentals on semi-molten reduction and smelting of laterite}

\subsection{Composition and phases of saprolite}

The composition of saprolite used in Lab is shown in Table 2. Phases of the ore include $\mathrm{Fe}_{2} \mathrm{O}_{3} \cdot \mathrm{H}_{2} \mathrm{O},(\mathrm{Mg}, \mathrm{Fe})_{2} \mathrm{SiO}_{4}, \mathrm{MgSiO}_{3}$ and $\mathrm{Mg}_{3} \mathrm{Si}_{2} \mathrm{O}_{5}(\mathrm{OH})_{4}$ etc. [6] The ore contains up to about $30 \sim 45 \%$ water, both as free moisture and also as chemically combined water in hydrated minerals.

Table 2. Composition of saprolite $/ \mathrm{wt} \%$.

\begin{tabular}{|c|c|c|c|c|c|c|c|c|c|c|}
\hline TFe & $\mathrm{Ni}$ & $\mathrm{SiO}$ & $\begin{array}{c}\mathrm{Al}_{2} \\
\mathrm{O}_{3}\end{array}$ & $\begin{array}{c}\mathrm{Ca} \\
\mathrm{O}\end{array}$ & $\begin{array}{c}\mathrm{Mg} \\
\mathrm{O}\end{array}$ & $\begin{array}{c}\mathrm{Mn} \\
\mathrm{O}\end{array}$ & $\mathrm{S}$ & $\mathrm{P}$ & $\mathrm{Cr}$ & $\begin{array}{c}\text { Burning } \\
\text { loss }\end{array}$ \\
\hline $20 \sim 25$ & $1.5 \sim 2$ & $20 \sim$ & $\sim 1.0$ & $\sim 0$. & $15 \sim$ & $\sim 0$. & $\sim 0$. & $\sim 0$. & $\sim 0$. & $30 \sim 45$ \\
& .0 & 30 & & 2 & 20 & 5 & 02 & 01 & 2 & \\
& & & & & & & & & & \\
\hline
\end{tabular}

\subsection{Thermodynamics of saprolite reduction at low temperature}

According to the main phases in saprolite, the reduction reactions are shown in Table 3 . Reaction temperature of nickel oxide with carbon is remarkably less than that of iron oxide with carbon, so nickel oxide is reduced easier than iron oxide. As shown in Fig.1, the equilibrium content of $\mathrm{CO} /\left(\mathrm{CO}+\mathrm{CO}_{2}\right)$ is over $70 \%$ for obtaining metal iron, if oxidizing atmosphere occurs, the fresh metal iron can be oxidized again. However, the equilibrium content of $\mathrm{CO} /\left(\mathrm{CO}+\mathrm{CO}_{2}\right)$ is very low(less than $\left.5 \%\right)$ for obtaining metal nickel, the fresh metal nickel can not be reoxidized easily. So the selective reduction can be realized by controlling ratio of carbon/oxygen and reactive atmosphere, and higher nickel content of ferronickel can be produced economically. 
Table 3. Thermodynamic data of nickel oxide and iron oxide reduced by carbon.

\begin{tabular}{|l|l|l|}
\hline Reaction & Gibbs energy & $\begin{array}{l}\text { Starting temperature of } \\
\text { reaction at standard } \\
\text { condition }\end{array}$ \\
\hline $\mathrm{NiO}+\mathrm{C}=\mathrm{Ni}+\mathrm{CO}_{(\mathrm{g})}$ & $\Delta \mathrm{G}^{\circ}=121470-173 \mathrm{~T}$ & $\mathrm{t}=429^{\circ} \mathrm{C}$ \\
\hline $\mathrm{FeO}+\mathrm{C}=\mathrm{Fe}+\mathrm{CO}_{(\mathrm{g})}$ & $\Delta \mathrm{G}^{\circ}=151880-153 \mathrm{~T}$ & $\mathrm{t}=720^{\circ} \mathrm{C}$ \\
\hline $\mathrm{Ni}_{2} \mathrm{SiO}_{4}+2 \mathrm{C}=2 \mathrm{Ni}+\mathrm{Si}+2 \mathrm{CO}_{(\mathrm{g})}$ & $\Delta \mathrm{G}^{\circ}=254680-352 \mathrm{~T}$ & $\mathrm{t}=450^{\circ} \mathrm{C}$ \\
\hline $\mathrm{Fe}_{2} \mathrm{SiO}_{4}+2 \mathrm{C}=2 \mathrm{Fe}+\mathrm{SiO}_{2}+2 \mathrm{CO}_{(\mathrm{g})}$ & $\Delta \mathrm{G}^{\circ}=331480-330 \mathrm{~T}$ & $\mathrm{t}=730^{\circ} \mathrm{C}$ \\
\hline
\end{tabular}
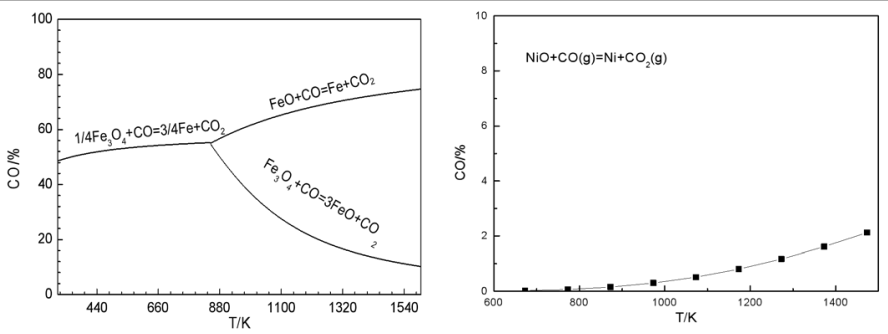

Fig.1. The equilibrium diagrams of iron oxide and nickel oxide reduced by $\mathrm{CO}-\mathrm{CO}_{2}$.

\subsection{Reduction and magnetic separation experiment}

The composition of chosen saprolite is shown in Table 2. The main reduction device is a vertical heating furnace. Fine coke is used as reducing agent, whose fixing carbon content is $85 \%$ and ash content is $12 \%$. Firstly, saprolite and fine coke are refined to $-74 \mu \mathrm{m}$ and then mixed in certain ratio. The $10 \mathrm{~g}$ mixed sample is put in a corundum crucible and then in a vertical heating furnace for reduction. Nitrogen was used as protective atmosphere.

The experimental parameters, such as temperature, time and ratio of carbon/oxygen, are carefully controlled to get higher reduction ratio of nickel. After reduction, the reduced sample is milled and magnetically separated to measure the separation efficiency of nickel.

As shown in Fig.2, at the conditions of $1150^{\circ} \mathrm{C}$ and $\mathrm{C}: \mathrm{O}=1: 1$, the reduction ratio of nickel is over $90 \%$ after $30 \mathrm{~min}$ reduction and the final ratio reaches $98 \%$. However, the reduction rate of iron oxide is slow, which reaches $75 \%$ after $30 \mathrm{~min}$ reduction and $90 \%$ after $60 \mathrm{~min}$. When the ratio of carbon/oxygen decreases from 1:1 to $0.8: 1$, the reduction rate of nickel oxide is still faster. It reaches $80 \%$ after $30 \mathrm{~min}$ reduction and $95 \%$ after $60 \mathrm{~min}$. The experiment result shows that the ratio of carbon/oxygen has a weak influence on nickel reduction, but it has a significant influence on iron reduction.
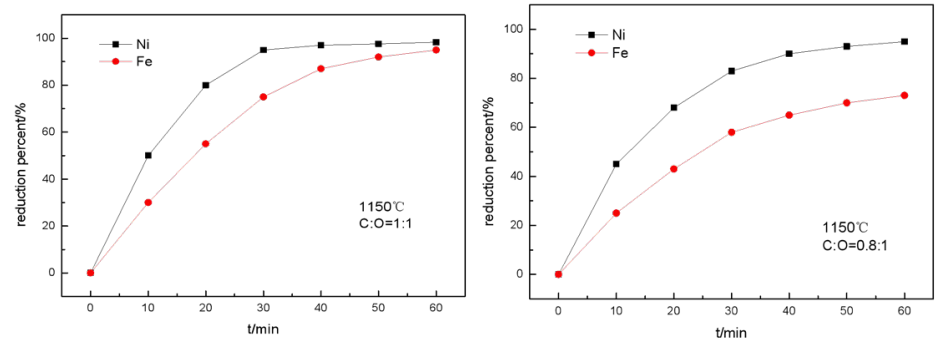

Fig.2. Effects of temperature, ratio of carbon/oxygen on reduction ratios of nickel and iron. 
After the reduction at $1150^{\circ} \mathrm{C}$, the megascopic ferronickel granules, diffused in the slag, are too small to be seen. Therefore, the mixture of reduced ferronickel fine and slag need to be crushed and magnetically separated. The yield of fine nickel is only $75 \%$ in the experiment.

\subsection{Effective separation of ferronickel from slag at the semi-molten condition}

According to the above results, nickel oxide is reduced easily and fine ferronickel can be obtained at $1150^{\circ} \mathrm{C}$, but separation efficiency is unsatisfactory. Slag and ferronickel can be separated at $1500^{\circ} \mathrm{C} \sim 1600^{\circ} \mathrm{C}$ in $\mathrm{BF}$ or RK-EF process, but high energy consumption is required. For saprolite, the amount of slag is much more than that of ferronickel and enthalpy of slag is also more than that of ferronickel, so for 1t ferronickel molten, much power is needed for melting slag.

Our R\&D team proposed a new route of efficiently separating ferronickel from slag at the semi-melting condition: the ferronickel granules with low melting point can be formed in slag by fast carburization at $1300^{\circ} \mathrm{C}$, then grow up and gather together due to surface tension and gravity. Theoretically, the complete separation of ferronickel and slag would be realized after enough time. In our experiment, the real smelting time is limited, so, a massive volume of ferronickel alloy is rarely found and alloy granules are bound by slag. The final size distribution of ferronickel granules is shown as follows: the granules larger than $5 \mathrm{~mm}$ are up to $70 \%$, the granules of $1 \sim 5 \mathrm{~mm}$ up to $20 \%$, and the fine particles less than $1 \mathrm{~mm}$ about $10 \%$.

\subsubsection{Melting points of ferronickel and slag}

Carbon content can decrease the melting point of ferronickel remarkably. When carbon content is about $4 \mathrm{wt} \%$, the melting point of ferronickel will be less than $1200^{\circ} \mathrm{C}$. On the contrary, nickel content has a pretty weak effect on the melting point of ferronickel. So the key measure to lower ferronickel melting point is to accelerate carburizing process [7].

Main phase of slag after smelting is magnesium silicate with a small amount of $\mathrm{FeO}$, $\mathrm{Al}_{2} \mathrm{O}_{3}$, and $\mathrm{CaO}$ in slag. As shown in Fig.3, there are two low melting regions in $\mathrm{CaO}-$ $\mathrm{MgO}-\mathrm{SiO}_{2}$ system, one is labelled as $\mathrm{A}$, and the other is labelled as $\mathrm{B}$. The composition of $\mathrm{A}$ is different from the ferronickel slag, so, we do not take A region into our consideration. Although the melting points are less than $1400^{\circ} \mathrm{C}$ in $\mathrm{B}$ region, a large amount of $\mathrm{CaO}$ needs to be replenished for saprolite smelting, leading to more power consumption. So, if $1300^{\circ} \mathrm{C}$ is chosen for smelting temperature of ferronickel, the mixture of alloy and slag is actually in semi-molten state.

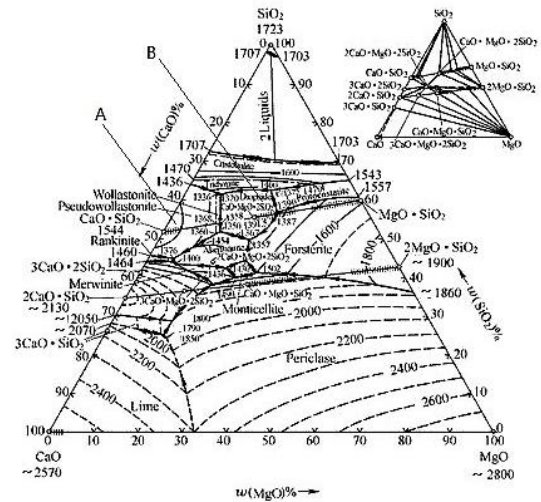

Fig.3. Phase diagram of $\mathrm{CaO}-\mathrm{MgO}-\mathrm{SiO}_{2}$ system. 


\subsubsection{Fast carburization}

It is easy to carburize ferronickel alloy at high smelting temperature during $\mathrm{BF}$ or $\mathrm{EF}$ process. However, the carburizing speed is slow in solid reduction process at $1100^{\circ} \mathrm{C} \sim 1300^{\circ} \mathrm{C}$. Solid reaction can be conducted in rotary and flush reactors. In rotary reactor, such as rotary kiln, charging materials rotate with rotary kiln. In flush reactor, such as rotary hearth furnace (RHF) or tunnel kiln (TK), charging materials move with hearth or pallet.

Semi-molten state can be realized so long as flame temperature arrives to $1400^{\circ} \mathrm{C}$ in rotary kiln and overturning materials can receive the energy from the flame evenly, so carburization can be conducted uniformly. Risk of semi-molten smelting in RK is the sticking problem. When materials move from low-temperature region to high temperature region, it is relatively safe, but semi-molten material moves from high temperature region to low temperature region, semi-molten materials start to cool, and it is possible to freeze in a certain area of the kiln.

For RHF or TK process, heating from material surface to inner is unidirectional. Heat radiation is of surface heating characteristics and the efficiency of heating the inner material mainly depends on heat conducting efficiency. So, the efficiency of this unidirectional heating is pretty low.

We developed a kind of microwave smelting technique to change the unidirectional heating style. The microwave is used to irradiate materials of $1150^{\circ} \mathrm{C}$ directly. It heats material very fast and is in favour of carburizing reaction. The microwave irradiation heating style include following advantages:

(1)Hot laterite ore can absorb more microwave energy with temperature increase .

(2)Carbon can adsorb much more microwave energy than slag and accelerate carburization reaction.

(3)Microwave changes traditional heating direction from surface to inner of materials. For flush reactor, microwave heats inner of materials directly and realizes heating from inner to surface.

\section{New process based on low-temperature reduction and microwave irradiation}

\subsection{Process description}

For decreasing electricity or coke consumption, the ferronickel smelting process based on low-temperature reduction and microwave irradiation has been developed. The first step is to dry laterite ores to decrease water content from $35 \%$ to $10 \%$. Waste heat is used for drying laterite ores in the drier. The second step is to refine laterite ores and anthracite coals. The third step is to manufacture green balls with uniform composition by batching, mixing and briquetting. The green balls are dried and conveyed to a long low-temperature reduction kiln, where the maximum reduction temperature is $1200^{\circ} \mathrm{C}$. Then, the heated and reduced balls are sent into a microwave equipment, where balls are heated up to $1300{ }^{\circ} \mathrm{C}$ and semi-molten smelting is realized to obtain ferronickel granules. The hot mixture of ferronickel and slag are water quenched and crushed. Then, the ferronickel granules are separated from slag magnetically. The fine ferronickel can be recycled as a sort of raw material and fine slag is used as an additive agent of cement. The $300{ }^{\circ} \mathrm{C}$ off gas in the reduction kiln is used for drying laterite and enters into cyclone and sack for dust eliminating, then enters CFD desulfurizer for removing sulphur, finally low temperature and clean off gas is discharged into atmosphere. 
Technological process is shown in Fig.4.

\subsection{The first demonstration line}

The first industrialized demonstration production line was installed in 2014. Its capacity is $100 \mathrm{kt}$ green balls /a. Some photographs from the demonstration factory and final product are shown in Fig.5 and Fig.6. The main raw material is saprolite, Ni and Fe Contents of the saprolite are $1.84 \%$ and $14.5 \%$ respectively. Pulverized coal is used as reducing agent and fuel. $\mathrm{Ni}, \mathrm{S}, \mathrm{P}$ contents are $13.5 \%, 0.2 \%$ and $0.025 \%$ respectively in the final ferronickel granules. The selective reduction is realized in the demonstration line.

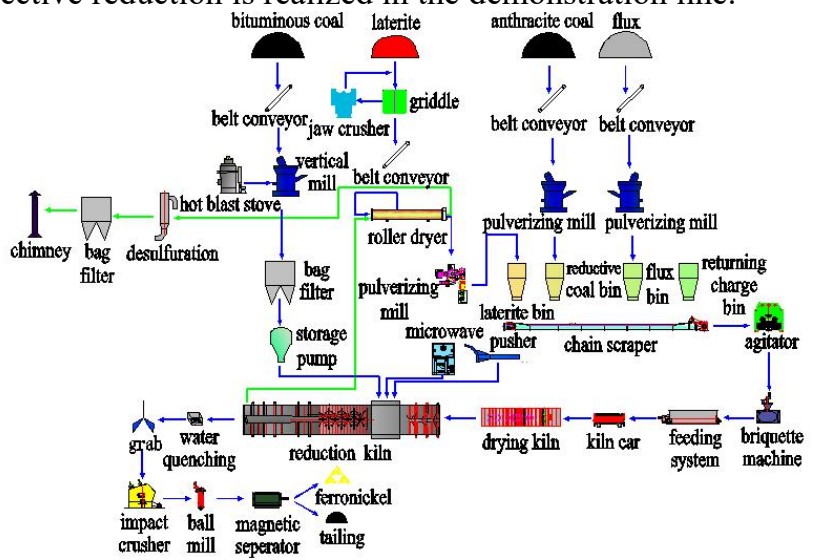

Fig.4. Process diagram of ferronickel smelting by low-temperature reduction and microwave irradiation.

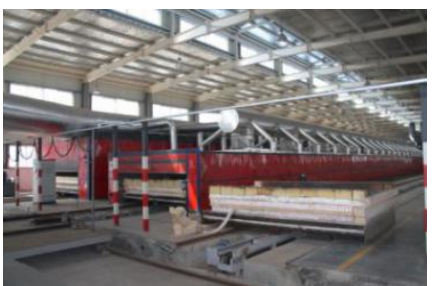

Low-temperature reduction kiln

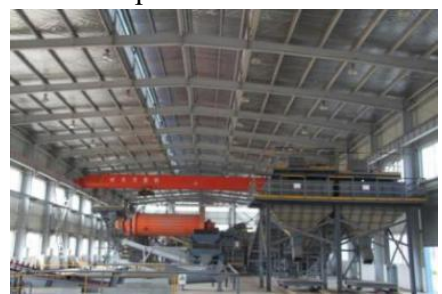

Ball milling and magnetic separation

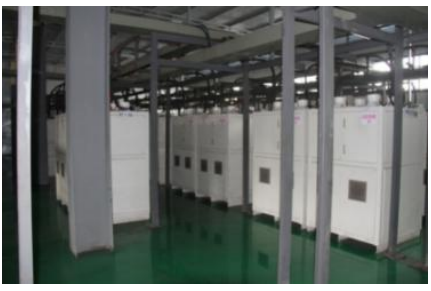

Microwave devices

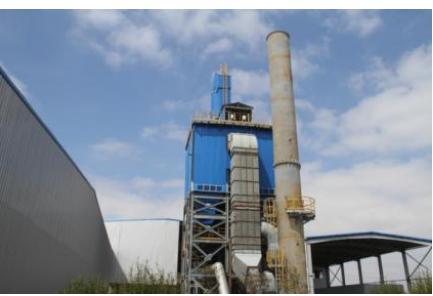

Environmental devices

Fig.5. Photographs from the demonstration production line.

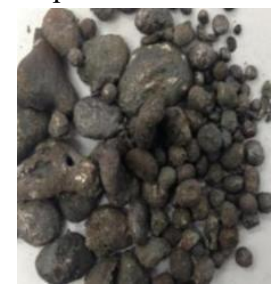

Fig.6. Morphology of ferronickel product. 


\section{Conclusions}

We invented a new smelting process to reduce laterite in the semi-melted state and set up a demonstration line for industrial production. The main results are as follows:

(1)Selective reduction of $\mathrm{Ni}$ from laterite strongly depends on the ratio of carbon to oxygen of the charge, i.e., optimized quantity of coal in the charge could lead to much higher nickel content of produced ferronickel granules.

(2)When laterite is reduced at $1150^{\circ} \mathrm{C}$, the yield ratio of nickel is over $95 \%$ but the efficiency of magnetic separation of ferronickel from slag is just $75 \%$.

(3)In the new process, the reduction is operated at $1300^{\circ} \mathrm{C}$ in the semi-melting state. The key technology is to realize a fast carburization by means of powerful microwave irradiation, which helps ferronickel fines diffuse and merge to larger sizes in the semimelting state for highly efficient separation.

(4)The first demonstration production line with this process has been constructed with an annual capacity of $100 \mathrm{kt}$ green balls. The nickel content of produced ferronickel granules reaches $13.5 \%$. The $\mathrm{P}$ and $\mathrm{S}$ contents are acceptable.

\section{Acknowledgements}

The presented research was financed by Projects from National Natural Science Foundation of China (U1560201).

\section{References}

1. Bingxi Geng. Steel \& Management, (2008)(6):27 29.

2. Yuting Hu. China Steel, (2007)(10):10 12.

3. Wuzhuang Zhao. World Nonferrous Metals, (2007)(3):5 8.

4. Huanhua He. China Nonferrous Metallurgy, 33(2004)(6):12 16.

5. Jingyou Chen, Juming Tan. Ferro-alloys, (2008)(3):13 16.

6. Rongqiu Peng. Nickel Metallurgy [M]. Changsha: Central South University Press, 2005.

7. Peimin Guo, Pei Zhao. Efficient Utilization of Metallurgical Resources [M]. Beijing: Metallurgical Industry Press, 2012. 